\title{
A statement on ethics from the HEART Group
}

Over the past several years, the editors of leading international cardiovascular journals have met to form the HEART Group and to discuss areas of growing, common interest. Recently, the HEART Group has developed a document that addresses general ethical principles in the conduct of the scientific process with which all of the editors concur. Published essentially simultaneously in all of the participating journals, including this journal, this document presents the ethical tenets accepted by all of the undersigned editors that will (continue to) guide their decisions in the editorial process.

These are the general principles on which the HEART Group is based and by which we, as a group, abide; however, please note that individual journal members and their respective societies may have their own rules and regulations that supersede the guidelines of the HEART Group.

\author{
Acta Cardiologica \\ Hugo Ector, MD, PhD \\ Editor-in-Chief \\ Patrizio Lancellotti, MD \\ Editor-in-Chief \\ American Journal of Cardiology \\ William C. Roberts, MD \\ Editor-in-Chief \\ American Journal of Geriatric Cardiology \\ Nanette K. Wenger, MD \\ Editor-in-Chief \\ Annals of Noninvasive Electrocardiology \\ Arthur J. Moss, MD \\ Editor-in-Chief \\ Canadian Journal of Cardiology \\ Eldon R. Smith, MD \\ Editor-in-Chief \\ Cardiology \\ Jeffrey S. Borer, MD \\ Editor-in-Chief \\ Cardiosource Review Journal \\ Kim A. Eagle, MD \\ Editor-in-Chief
}

\author{
Cardiovascular Drug Reviews \\ Jane Freedman, MD \\ Incoming Editor-in-Chief \\ Henry Krum, PhD \\ Incoming Editor-in-Chief \\ Chim Lang, MD \\ Incoming Editor-in-Chief
}
Cardiovascular Drugs and Therapy
Willem J. Remme, MD, PhD
Editor-in-Chief

\section{Cardiovascular Research \\ Hans Michael Piper, MD, PhD \\ Editor-in-Chief}

Catheterization and Cardiovascular Interventions

Christopher J. White, MD

Editor-in-Chief

\section{Circulation}

Joseph Loscalzo, MD, PhD

Editor-in-Chief

Circulation Research

Eduardo Marbán, MD, PhD

Editor-in-Chief 
Coronary Artery Disease

Burton E. Sobel, MD

Editor

Current Opinion in Cardiology

Robert Roberts, MD

Editor

Current Problems in Cardiology

Shahbudin H. Rahimtoola, MD

Editor

Europace

A. John Camm, MD

Editor-in-Chief

European Heart Journal

Frans Van de Werf, MD

Editor-in-Chief

European Journal of Heart Failure

Karl Swedberg, MD, PhD

Editor-in-Chief

Heart

Adam D. Timmis, MD

Editor

Heart \& Lung: The Journal of Acute and Critical Care

Kathleen S. Stone, PhD, RN

Editor-in-Chief

Heart Rhythm

Douglas P. Zipes, MD

Editor-in-Chief

International Journal of Interventional

Cardioangiology

David G. Iosseliani, MD

Editor-in-Chief

Journal of Cardiovascular Computed Tomography

Allen J. Taylor, MD

Editor-in-Chief

Journal of Cardiovascular Pharmacology

Michael R. Rosen, MD

Editor

Journal of Interventional Cardiology

Cindy L. Grines, MD

Editor-in-Chief

Journal of the American College of Cardiology

Anthony N. DeMaria, MD

Editor-in-Chief
JACC: Cardiovascular Imaging

Jagat Narula, MD, PhD

Editor-in-Chief

JACC: Cardiovascular Interventions

Spencer B. King III, MD

Editor-in-Chief

Journal of Electrocardiology

Galen S. Wagner, MD

Editor-in-Chief

Journal of Interventional Cardiac

Electrophysiology

Sanjeev Saksena, MD

Editor-in-Chief

Journal of the American Society of

Echocardiography

Alan S. Pearlman, MD

Editor-in-Chief

Journal of Heart Valve Disease

Endre Bodnar, $\mathrm{MD}, \mathrm{PhD}$

Editor-in-Chief

Robert W. Emery, MD

Incoming Editor-in-Chief

Journal of Thoracic and Cardiovascular Surgery

Lawrence H. Cohn, MD

Editor-in-Chief

Netherlands Heart Journal

Ernst E. van der Wall, MD

Editor-in-Chief

Pediatric Cardiology

Ra-id Abdulla, MD

Editor-in-Chief

Progress in Cardiovascular Diseases

Michael Lesch, MD

Editor

Revista Española de Cadiología

Fernando Alfonso, MD, PhD

Editor-in-Chief

Scandinavian Cardiovascular Journal

Rolf Ekroth, MD

Chief Editor 


\section{Ethics}

The purpose of this is to ensure transparency and honesty in the scientific process that promotes ethical conduct in the performance and publication of research. The following will be considered as parts of this process:

a. Disclosure of potential conflicts of interest for all involved in the performance of research and in the evaluation and publication process of a manuscript. Relevant relationships with commercial interests will be defined in terms of levels and nature of support. The nature of support will be listed as grants, supplies/equipment, type of employment, or personal income. Equity and royalty interests should be stated as well as any fiduciary relationship with the sponsor.

b. Establish thorough review processes particularly alert to discovering scientific fraud and data falsification, redundant or duplicate publication, and plagiarism, and to adopt a uniform standard of dealing with authors guilty of fraudulent practices.

c. Maintain confidentiality and embargos where appropriate.

d. Create uniform criteria to establish authorship. To qualify for authorship, individuals must have made substantial contributions to the intellectual content of the paper in at least one of the following areas: conceived and designed the research; acquired the data; analysed and interpreted the data; performed statistical analysis; handled funding and supervision; drafted the manuscript; or made critical revision of the manuscript for important intellectual content. Authors must give final approval of the version to be submitted and any revised version to be published. For multicentre trials, individuals who accept direct responsibility for the manuscript should fully meet the criteria for authorship previously defined; contributors not meeting these criteria should be acknowledged.

e. Note avoidance of false claims of ownership and priority, by attention to previous publications.

f. Establish avoidance of excessive claims of benefits of a product/technique in the publication as well as with news media.

g. Note compliance with institutional review board requirements and, when appropriate, approved laboratory procedures for animal research, and that the research conforms to the ethical standards of the Declaration of Helsinki, the Geneva Declaration, the Belmont Report, and Good Clinical Practices from the FDA, and the submission conforms to the International Committee of Medical Journal Editors (ICMJE) 'Uniform Requirements for Manuscripts Submitted to Biomedical Journals: Writing and Editing for Biomedical Publication' (www.ICMJE.org). 